\title{
COMPARISON OF OSTRACODA (CRUSTACEA) SPECIES COMPOSITION BETWEEN LAKES AND STREAMS AT HIGH ELEVATIONS IN TURKEY
}

\author{
Mehmet Yavuzatmaca \\ Bolu Abant Izzet Baysal University, Faculty of Arts and Science, Department of Biology \\ Gölköy 14280,Bolu, Turkey; E-mail: yavuzatmaca46@gmail.com; yavuzatmaca_m@ibu.edu.tr \\ https://orcid.org/0000-0002-0398-6763
}

\begin{abstract}
Ostracods are one of the most suitable organisms because of their ecological and morphological preferences for habitat types to study the diversity between streams and lakes. In this study, 24 streams and 16 lakes were sampled in 2019 to evaluate the species compositions between streams and lakes. Environmental heterogeneity in the sense of the physicochemical variables was found among the habitats. 24 of the 29 species with 923 individuals were found in the lakes when 13 species with 898 individuals were found in the streams. Eight species were common in both habitat types. Species contributing about $70.81 \%$ to the significant differences in the species composition between the habitats showed cosmopolitan characteristics. Species variation among the replicates of lakes was higher than streams. Results indicated that the species composition was probably associated to dissolved oxygen and electrical conductivity in lakes and streams, respectively. Overall, results suggested that the determination of influential local factors (e.g., dissolved oxygen, electrical conductivity) in different aquatic bodies can provide important contributions to the estimation of which habitat types can be chosen by species and the use of species as bioindicators.
\end{abstract}

Key words: elevational range, lotic and lentic, benthonic and nektonic, environmental heterogeneity, cosmopolitan species, Ostracoda, Crustacea.

\section{INTRODUCTION}

Waters flowings in one direction along a slope are called lotic (e.g., streams, rivers), but stagnant water bodies (e.g., lakes) are termed as lentic habitats. Unlike lotic systems, lakes bear different water flows regimes into, out, and throughout their basins (WETzeL 2001). These flowing regimes cause the variability of water renewal times of lentic habitats when compared to lotic habitats with continuous water renewal times (WeTzel 2001). This allows distinguishing the lotic and lentic habitats environmentally and spatiotemporally (Hof et al. 2008). In addition, both habitat types also show differences in the physico-chemical parameters (e.g., $\mathrm{pH}$, dissolved oxygen, etc.) (MisHra \& YADAV 1978, Lottig et al. 2011), which lead to change species compositions. Recently, Dunn et al. (2020) underlined the prevailing of Ephemeroptera, Plecoptera, and Trichoptera in lotic habitats while micro-crustaceans like Copepoda, Cladocera, and Ostracoda in lentic habitats. 
Ostracods, one of the small crustaceans (0.3-5 mm long), are found in various aquatic habitats, from marine to freshwaters (МеIsch 2000). They can be carried out over long distances via vectors (e.g., birds, humans) (McKenzIE \& Moroni 1986), but they can change their location using their swimming setae on their second antennae (A2) in the habitats where they live. Due to the presence of swimming setae on A2, they are categorized as 1) nektonic species that have swimming setae reaching and/or passing to the tips of terminal claws of A2, and 2) benthonic species that bear reduced swimming setae extending up to the middle of the penultimate seta of A2 or shorter (Meisch 2000). Along with the physico-chemical parameters of aquatic bodies (KüLKÖYLÜOĞLU 2013), habitat type is showed as one of the important environmental variables for the occurrence and composition of ostracods (MARMONIER et al. 1994, KüLKÖYLÜOĞLU 2004). Higuti et al. (2007) declared the association of freely swimming ostracods with littoral (non-floating) macrophyte beds of lakes in the Paraná River floodplain (Brazil) and then AкDEmír et al. (2016) stated the preferences of non-swimming ostracod species for lotic rather than lentic systems. KüLKöYLüOĞLU et al. (2019a) reported that benthonic ostracods might prefer unstable aquatic bodies (lotic) rather than stable aquatic bodies (lentic) when compared with nektonic species. From the information mentioned above, one can interpret that both systems (lotic and lentic) can be an essential factor in ostracod species' occurrence. What matters here is whether the morphological characteristics (e.g., swimming setae) or ecological tolerances of the species are more important in these habitat preferences. Most recently, YAVUZATMACA (2020a) pinpointed the importance of ecological tolerance of species rather than a morphological character for the habitat preferences, but he also underlined that more works are needed to clarify this issue. Therefore, studies discussing this issue will make a significant contribution to use ostracods as habitat indicators.

While evaluating ostracod distribution and their ecological and habitat preferences, the importance of elevation should not be ignored as a regional factor. In literature, the effect of elevation on the distribution of ostracods is still a controversial issue (e.g., Yavuzatmaca et al. 2018, Yavuzatmaca 2019 and citations therein). Although the conducted studies gave different results, it is widely believed that elevation is not the primary factor, but as a secondary factor, it affects the distribution of ostracods. Yavuzatmaca et al. (2018) and references therein discussed it in detail and supported the secondary effect of elevation on the distribution of ostracods. This is because of the dependence of the air and water temperatures on the elevation, and then changes of physico-chemical parameters due to the water temperature fluctuations in water played an important role to support this view. DeHLing et al. (2010) used elevation as a factor for habitat diversity in a region and reported that widening of elevation range resulting in a decrease in species richness for lentic but 
an increase for lotic habitats. Also, citations in the same study suggested an ascending species richness for lotic and lentic habitats along with the elevational range extending. In the sense of ostracods, KüLKöYLÜOĞLU et al. (2016) proposed a clear relationship between habitat diversity and species richness in Çankırı province (Turkey). In the light of this information, the change in ostracod species richness in a region with the widening and narrowing of the elevational range as a factor of habitat diversity is one of the issues that need to be investigated because such information contributes to environmental protection and biodiversity studies both in time and economically. Apart from the discussion relating to elevation, elevation as a habitat diversity factor will be examined by comparing the results of the present study with the literature for ostracods. Along with this important point of this study, (1) testing of hypothesis, "no difference in the species composition between streams and lakes", (2) determination of the effectiveness of dissolved oxygen, water temperature, electrical conductivity, $\mathrm{pH}$ and elevation on the distribution of ostracods, and (3) estimation of ecological tolerance and optimum values of species are the other main objectives of the study.

\section{MATERIAL AND METHODS}

Study area - The present study was conducted in the borders of 6 provinces located in the Black Sea (Artvin) and Eastern Anatolia (Erzurum, Ardahan, Kars, Van, and Bitlis) of Turkey (Fig. 1). According to Köppen-Geiger climate classification systems, temperate oceanic (Artvin), warm-summer humid continental (Artvin, Erzurum, Ardahan, and Kars), Mediterranean influenced warm-summer humid continental (Van and Bitlis), and the Mediterranean influenced hot-summer humid continental (Bitlis) climates are commonly observed in the borders of studied provinces (Climate-Data.org 2020). Sixteen lakes with an elevation range from 1007 (L16) to 2358 (L12) m asl. and 24 streams with the elevation ranging from 1510 (S12) to 2340 (S2) m asl. were chosen for the ostracod samplings (Fig. 1). Six lakes (L1, L3, L8, L11, L12, and L16) and five streams (S7, S10, S19, S22, and S24) were sampled once in June when the rests were sampled three times in June, July-August, and September of 2019. Among streams, S1, S2, S5, S10, S12, S13, S21 and S24 are the second (2nd) order streams according to the Strahler stream ordering method (STRAHLER 1957), and others are the first (1st) order streams. All the sampled lakes and streams have permanent waters.

Geographical data (elevation and coordinates) (Tables S1 and S2) were recorded in situ with a GARMIN etrex Vista H global position system. To obtain the accurate values of environmental variables, dissolved oxygen concentration (DO, $\mathrm{mg} / \mathrm{L})$, water temperature $\left(\mathrm{Tw},{ }^{\circ} \mathrm{C}\right)$, electrical conductivity $(\mathrm{EC}, \mu \mathrm{S} / \mathrm{cm})$ and $\mathrm{pH}$ were measured before ostracod sampling by a YSI Professional Plus multi-probe device (Table S2).

Sampling - To collect ostracod samples, a standard sized hand net $(200 \mu \mathrm{m}$ in mesh size) was used to gather $2-3 \mathrm{~cm}$ of upper surface of sediments and swept into the water body. Samples were collected up to a $1 \mathrm{~m}$ depth covering $1 \mathrm{~m}^{2}$ area from the littoral region of lakes and from slow-flowing riparian zones of streams and subsequently fixed in $70 \%$ ethanol in $250 \mathrm{ml}$ plastic bottles in situ. 
Laboratory analyses - After washing samples under pressurized tap water, ostracod specimens were separated from the sediments under an Olympus ACH 1X stereomicroscope. Taxonomic keys provided in Meisch (2000) and Karanovic (2012) were used for the identification of species based on using both soft body parts and the morphology of carapaces under a light microscope (Olympus BX-51).

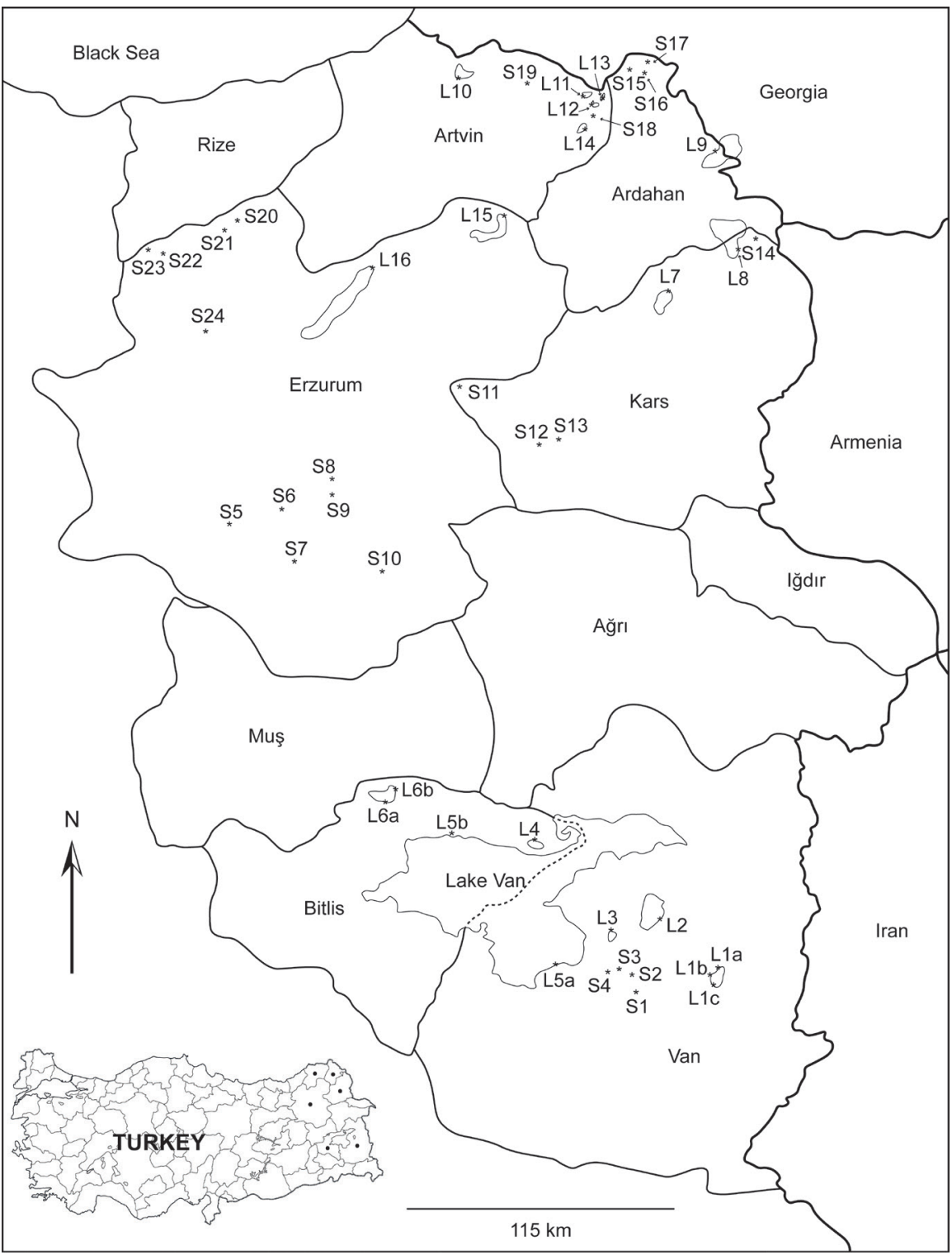

Fig. 1. Location of 16 lakes and 24 streams studied in the present study. L and S indicate lake and stream, respectively. Lowercase $\mathrm{a}, \mathrm{b}$ and $\mathrm{c}$ show the multiple samplings in a lake 
Statistical analyses - Independent-Samples t-test, along with the application of posthoc analysis, was used to test significant differences in the mean values of environmental variables between lakes and streams (IBM-SPSS Statistics Version 21). When homogeneity of variance and normality of data was not fulfilled, the Mann-Whitney U test is run. A diversity permutation test with 9999 random matrices was performed to compare species richness and abundance of ostracods between lakes and streams (PAST 3.26 software (Hammer et al. 2001)). To estimate species diversity, Shannon index values of lakes and streams were calculated using Species Diversity and Richness 4 software (SEABY \& HeNDERSON 2006). Possible significant correlations between Shannon index values and environmental variables for lakes and streams were checked by Spearman Correlation Analysis (IBM-SPSS Statistics Version 21). Species were categorized as eudominant $(32-100 \%)$, dominant $(10-31 \%)$, subdominant $(0.32-9 \%)$, recedent $(1-3.1 \%)$, subrecedent $(0.32-$ $0.99 \%)$ and sporadic $(<0.31 \%)$ according to their abundance percentages (Rомвасн 1999). A nonparametric Multivariate Permutational Variance Analysis, PERMANOVA, (ANDERson 2001) was applied to test the null hypothesis "no difference in the species composition between streams and lakes". Bray-Curtis and a total of 999 permutations were used as a dissimilarity matrix, and to measure the significance of differences, respectively (PRIMER 7.0 software package (CLARKE \& GoRLEy 2015)). Multivariate dispersion (MVDISP) indices were calculated (WARWICK \& CLARKE 1993) to evaluate numerical indices of similarity among replicates of lakes and streams. In which, values closer to zero indicate no difference when larger values mean crucial dissimilarity. Variation in species composition, beta diversity, with the use of Bray-Curtis dissimilarity measure between lakes and streams, was calculated using Permutational Analysis of Multivariate Dispersions (PERMDISP) based on distances between sample units and centroid of the group (ANDERson 2006, ANDERSON et al. 2006) and then its significance was tested with permutations (999 replicates). PERMANOVA (streams $=$ or $\neq$ lakes) and PERMDISP $($ streams - streams $=$ or $\neq$ lakes lakes) test whether classes of each habitat type show differences in their variability in species composition (beta diversity) and in their within-classes dispersion or beta diversity, respectively. Also, PERMANOVA and PERMDISP with Euclidian distance matrixes were applied to test environmental variables composition and environmental heterogeneity between streams and lakes, respectively. Analysis of Similarity Percentage (SIMPER) was run to see which species or environmental variables is/are responsible for differences in species or environmental composition between lakes and streams when the PERMANOVA indicated a significant result (CLARKE \& WARWICK 2001). All these multivariate statistical analyses were carried out with the PRIMER 7.0 software package. Principal Coordinate Analysis (PCoA) was applied with the same data used in PERMANOVA to visualize (dis)similarity of ostracod species composition between the streams and lakes (PAST 3.26 Software). Detrended Correspondence Analysis revealed that the longest gradient length was smaller than 3 for lakes and between 3 and 4 for streams (Table S3). In this situation, using a linear method was suggested by ter BraAK \& Šmilauer (2002). Therefore, Redundancy Analysis (RDA) was performed using CANOCO 4.5 software to explore relationships between environmental variables and ostracod species that occurred three or more times during the sampling, and the significance of variables was tested with Monte Carlo permutation test (499 permutations). Ecological optima (Opt) and tolerance (Tol) values of species seen at least three times for explanatory factor(s) were estimated by a transfer function of weighted averaging regression used in C2 Software (JugGins 2003). All analyses were carried out with undamaged adult individuals, and analyses relating to environmental variables were done for sampling sites bearing living adult individuals. 


\section{RESULTS}

Mean values of electrical conductivity $(Z=-2.82, p=0.005$, Mann-Whitney $U$ test), water temperature $(t=2.83, p=0.006$, Independent samples $t$ test $)$, and $\mathrm{pH}(\mathrm{t}=2.80, \mathrm{p}=0.007$, Independent samples $\mathrm{t}$-test $)$ indicated significant differences between lakes and streams while elevation $(Z=-1.28, p=$ 0.199 , Mann-Whitney U-test) and dissolved oxygen concentration $(Z=-0.51$, $\mathrm{p}=0.61$, Mann-Whitney U-test) did not show significant differences (Fig. S1). PERMANOVA indicated a significant difference found in the variability of environmental gradients between lakes and streams (Pseudo-F $=16.296$, $\mathrm{p}=0.001)$. According to the SIMPER, electrical conductivity had great contribution $(99.83 \%)$ to this difference. Environmental heterogeneity amid the lakes and streams (average distance of centroid and standard error in lakes $=$ $7324.4 \pm 928.47$ and in streams $=235.37 \pm 14.30)$ were significant $(\mathrm{F}=87.019, \mathrm{p}=$ 0.001). Results demonstrated that these habitat types had different environmental characteristics.

A total of 1821 individuals belonging to 29 ostracod species were reported in the present study (Tables 1 and S1). There is a significant difference $(p<0.05)$ in species richness and abundance between lakes (24 spp. and 923 ind.) and streams (13 spp. and 898 ind.). The number of nektonic species (species freely swimming, $4 \mathrm{spp}$.) is smaller than those of benthonic species (nonswimmer, 9 spp.) in streams, but these numbers are very close to each other in lakes (nektonic $=13 \mathrm{spp}$. and benthonic $=11 \mathrm{spp}).($ see Table 1$)$.

Shannon diversity index values of lakes and streams were ranged from 0.07 (L8 in June) to 1.251 (L15 in June), and from 0.23 (S16 in September) to 1.06 (S23 in July-August) with all index values equal to 2.151, and 1.187, respectively. Shannon index value showed moderately significant negative correlation with $\mathrm{pH}\left(\mathrm{r}_{\mathrm{s}}=-0.41, \mathrm{p}<0.05\right)$ but positive with dissolved oxygen $\left(\mathrm{r}_{\mathrm{s}}=\right.$ $+0.40, p<0.05$ ) in lakes. In streams, no significant results were determined.

PERMANOVA revealed a significant distinctness in the species composition (Pseudo-F $=7.93, p=0.001$ ) between lakes and streams (Fig. 2). Eight species (Cypridopsis vidua, Heterocypris incongruens, Ilyocypris bradyi, I. gibba, Neglecandona neglecta, Potamocypris fallax, Pseudocandona albicans, and Psychrodromus olivaceus) were common in both habitat types (Table 1 and Fig. 2). However, only I. bradyi was found as eudominant in both habitat types among these species, while C. vidua and I. gibba recorded from streams, and N. neglecta from lakes were sporadic species (see Table 1). SIMPER showed $70.81 \%$ contributions of first seven species (Limnocythere inopinata (19.33\%), I. bradyi (14.26\%), P. olivaceus (9.64\%), C. vidua (8.04\%), P. fallax (7.46\%), Cypria ophtalmica $(6.16 \%)$ and $N$. neglecta $(5.92 \%)$ ) to the $99.17 \%$ of average dissimilarity between both habitat types. 
Table 1. Number of individuals (abundance), dominance percentage (\%) and locomotory ability of ostracod taxa in lakes and streams from June to September. DL $=$ dominance $\%$ in lakes, DS $=$ dominance \% in streams, $\mathrm{L}=$ locomotory ability, $\mathrm{N}=$ nektonic, $\mathrm{B}=$ benthonic, VI = June, VII-VIII = July-August, IX = September.

\begin{tabular}{|c|c|c|c|c|c|c|c|c|c|c|}
\hline \multirow[b]{2}{*}{ Species } & \multirow[b]{2}{*}{ Code } & \multicolumn{3}{|c|}{ Lakes } & \multicolumn{3}{|c|}{ Streams } & \multirow{2}{*}{ DL } & \multirow{2}{*}{ DS } & \multirow{2}{*}{$\mathrm{L}$} \\
\hline & & VI & VII-VIII & IX & VI & VII-VIII & IX & & & \\
\hline Cypria ophtalmica & Co & 20 & 26 & 12 & & & & 6.28 & & $\mathrm{~N}$ \\
\hline Cypris pubera & $\mathrm{Cp}$ & 5 & & & & & & 0.54 & & $\mathrm{~N}$ \\
\hline Cypridopsis vidua & $\mathrm{Cv}$ & 34 & 50 & 10 & 1 & & & 10.18 & 0.11 & $\mathrm{~N}$ \\
\hline Fabaeformiscandona balatonica & $\mathrm{Fb}$ & & & & & 6 & & & 0.67 & B \\
\hline Fabaeformiscandona sp.1 & Fp1 & & & & 1 & & & & 0.11 & B \\
\hline Fabaeformiscandona sp. 2 & Fp2 & & 5 & 2 & & & & 0.76 & & B \\
\hline Heterocypris incongruens & $\mathrm{Hi}$ & & 66 & 1 & 3 & 12 & 1 & 7.26 & 1.78 & $\mathrm{~N}$ \\
\hline Heterocypris salina & Hs & & & & & 4 & 22 & & 2.90 & $\mathrm{~N}$ \\
\hline Ilyocypris bradyi & $\mathrm{Ib}$ & 320 & & & 5 & 60 & 308 & 34.67 & 41.54 & B \\
\hline Ilyocypris decipiens & Id & & & 3 & & & & 0.33 & & B \\
\hline Ilyocypris gibba & $\operatorname{Ig}$ & & 6 & & & 1 & & 0.65 & 0.11 & $\mathrm{~N}$ \\
\hline Ilyocypris monstrifica & $\operatorname{Im}$ & 36 & & & & & & 3.90 & & $\mathrm{~N}$ \\
\hline Limnocythere inopinata & $\mathrm{Li}$ & 122 & 21 & 25 & & & & 18.20 & & B \\
\hline Limnocytherina sanctipatricii & Ls & 1 & 4 & 2 & & & & 0.76 & & B \\
\hline Neglecandona neglecta & $\mathrm{Nn}$ & & 1 & & 4 & 18 & 54 & 0.11 & 8.46 & B \\
\hline Physocypria kraepelini & $\mathrm{Pk}$ & 2 & & & & & & 0.22 & & $\mathrm{~N}$ \\
\hline Plesiocypridopsis newtoni & $\mathrm{Pn}$ & 14 & 35 & 3 & & & & 5.63 & & $\mathrm{~N}$ \\
\hline Potamocypris fallax & $\mathrm{Pf}$ & 1 & 1 & & 19 & 33 & 38 & 0.22 & 10.02 & B \\
\hline Potamocypris pallida & $\mathrm{Pp}$ & & 29 & & & & & 3.14 & & B \\
\hline Potamocypris similis & Ps & & & & 10 & 55 & 59 & & 13.81 & B \\
\hline Potamocypris unicaudata & $\mathrm{Pu}$ & & & 1 & & & & 0.11 & & $\mathrm{~N}$ \\
\hline Potamocypris variegata & $\mathrm{Pv}$ & & 6 & & & & & 0.65 & & $\mathrm{~N}$ \\
\hline Potamocypris zschokkei & $\mathrm{Pz}$ & & 2 & & & & & 0.22 & & B \\
\hline Pseudocandona albicans & $\mathrm{Pa}$ & 1 & 13 & 2 & 1 & 3 & & 1.73 & 0.45 & B \\
\hline Psychrodromus olivaceus & Po & 4 & & 1 & 24 & 61 & 87 & 0.54 & 19.15 & B \\
\hline Psychrodromus robertsoni & $\operatorname{Pr}$ & & & & & 6 & 2 & & 0.89 & B \\
\hline Stenocypria fischeri & Sf & 33 & & & & & & 3.58 & & $\mathrm{~N}$ \\
\hline Trajancypris clavata & Tc & 1 & & & & & & 0.11 & & $\mathrm{~N}$ \\
\hline Trajancypris serrata & Ts & 2 & & & & & & 0.22 & & $\mathrm{~N}$ \\
\hline Richness & & 15 & 14 & 11 & 9 & 11 & 8 & & & \\
\hline Number of individuals & & 596 & 265 & 62 & 68 & 259 & 571 & & & \\
\hline
\end{tabular}


Samples of lakes (1.139) were indicated higher dissimilarities than streams (0.938) based on MVDISP. These results corroborated with SIMPER that displayed low similarity percentages in the lakes $(10.18 \%)$ than streams $(11.97 \%)$. Variability of species composition between lakes and streams did not show significant differences $(\mathrm{F}=0.37, \mathrm{p}=0.563)$ when the average distance to centroid was 63.642 in lakes and 62.563 in streams.

The first two axes of Redundancy Analysis (RDA) explained high percentages of relationships between species (distribution + abundance) and environmental variables in lakes (89.5\%) and streams (98\%) (Table S3). In lakes, dissolved oxygen concentration (DO) exhibited a significant effect $(\lambda=0.21$, $\mathrm{F}=6.35, \mathrm{p}=0.002$ ) on the distribution and abundance of species, while some of the other variables (electrical conductivity $(\mathrm{EC}, \lambda=0.07, \mathrm{~F}=2.63, \mathrm{p}=0.056)$, elevation (Elev, $\lambda=0.08, \mathrm{~F}=2.47, \mathrm{p}=0.062$ ), water temperature (Tw, $\lambda=0.06$, $\mathrm{F}=2.09, \mathrm{p}=0.114)$ and $\mathrm{pH}(\lambda=0.01, \mathrm{~F}=0.46, \mathrm{p}=0.678))$ were not significant. Stenocypria fischeri and Limnocytherina sanctipatricii presented close relationships with DO and EC, respectively, while the distribution and abundance of L. inopinata were correlated with $\mathrm{pH}$ and $\mathrm{Tw}$ (see Fig. 3a). In streams, a meaningful effect of EC $(\lambda=0.11, F=5.43, p=0.008)$ was found on the distribution of species while the effects of DO $(\lambda=0.02, \mathrm{~F}=1.03, \mathrm{p}=0.328)$, Elev $(\lambda=0.01$, $\mathrm{F}=0.52, \mathrm{p}=0.586), \mathrm{pH}(\lambda=0.01, \mathrm{~F}=0.34, \mathrm{p}=0.750)$ and $\mathrm{Tw}(\lambda=0.01, \mathrm{~F}=0.16$, $\mathrm{p}=0.918$ ) were insignificant. Abundance and distribution of $H$. incongruens, $H$. salina, $P$. albicans and I. bradyi showed positive associations with Tw but $N$. neglecta exhibited a negative relationship. Potamocypris similis displayed a negative correlation with EC (Fig. 3b). Estimated optimum (Opt) and toler-

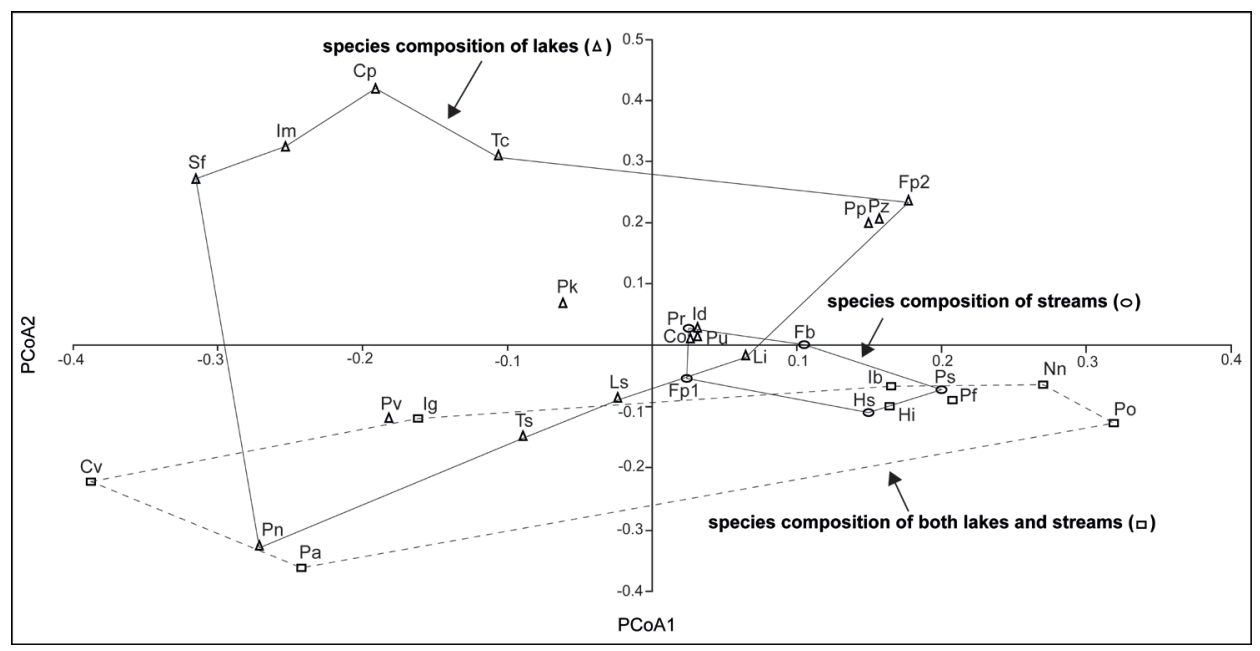

Fig. 2. Principal coordinate result for the variability in the species composition between lakes and streams 


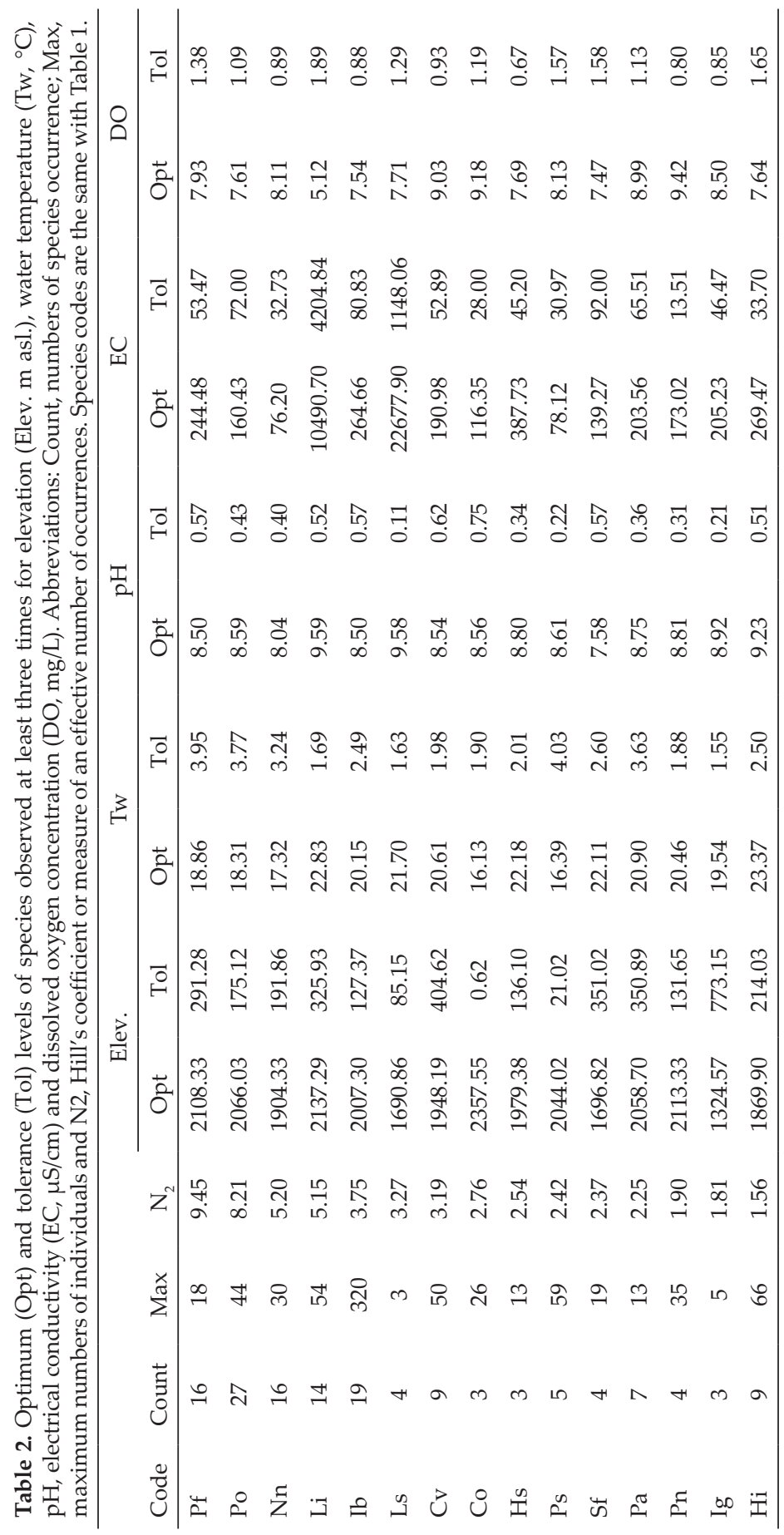


ance (Tol) values of individual species for five environmental variables (Elev, $\mathrm{Tw}, \mathrm{pH}, \mathrm{EC}$ and DO) were presented in Table 2. Accordingly, L. sanctipatricii $(22677.90 \mu \mathrm{S} / \mathrm{cm})$ displayed highest EC optimum value, followed by L. inopinata $(10490.70 \mu \mathrm{S} / \mathrm{cm})$ whereas $N$. neglecta $(76.20 \mu \mathrm{S} / \mathrm{cm})$ exhibited lowest optimum value (see Table 2 ).

The results of the ostracod studies collected from literature and their comparison with the present study concerning the elevational range are given in Fig. 4. Although there is not a certain upward or downward trend at first glance, the slope line shows that the richness of species increases along with the elevational range, albeit a little, regardless of the number of stations (or sites) sampled and seasonality. Of course, these studies were taken as a whole since no lotic or lentic distinction was made. Of them, studies covering seasonality and separation of lakes and streams resulted in 18 species (spp.) from 15 stations at a range of $2757 \mathrm{~m}$ in Yavuzatmaca (2020b), $17 \mathrm{spp}$. from 21 stations at a range of $1719 \mathrm{~m}$ in Yavuzatmaca (2020a) and $26 \mathrm{spp}$. from 16 stations at a range of $1352 \mathrm{~m}$ in the present study for lakes, when $17 \mathrm{spp}$. from 41 stations at a range of $1423 \mathrm{~m}$ in Yavuzatmaca (2020a), $12 \mathrm{spp}$. from 25 stations at a range of $1103 \mathrm{~m}$ in Yavuzatmaca (2020b) and 13 spp. from 24 stations at a range of $830 \mathrm{~m}$ in the present study for streams. However, these results should not be generalized now, and the effect of elevational range on the species richness of ostracods should be tested in future studies.
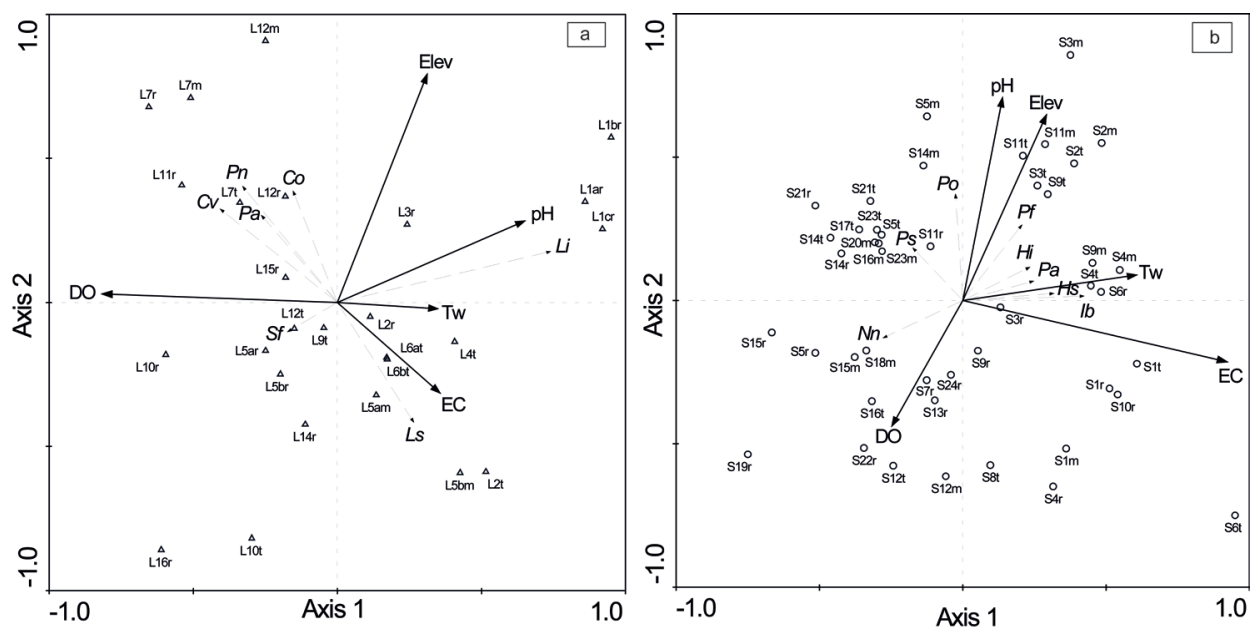

Fig. 3. RDA results showing ordination of ostracod species (dashed arrows), samples (triangles and circles), and environmental variables (solid arrows) in lakes (a) and streams (b). Abbreviations: $\mathrm{L}=$ lake, $\mathrm{S}=$ stream, $\mathrm{r}=$ spring season, $\mathrm{m}=$ summer season, $\mathrm{t}=$ fall season, $\mathrm{Elev}=$ elevation, $\mathrm{DO}=$ dissolved oxygen, $\mathrm{EC}=$ electrical conductivity and $\mathrm{Tw}=$ water temperature. Codes of species were given in Table 1 


\section{DISCUSSION}

Along with the distinctness in the flow regimes of the studied lakes and streams at high altitudes in the present study, environmental variable composition unlikeness of them were found in terms of water temperature (Tw), $\mathrm{pH}$ and especially in electrical conductivity (EC). This result conforms to the findings of Lotтig et al. (2011), who noted the significant chemical differences between streams and lakes because of the inputs (flow regimes) to them. In addition, the negative relationships of these variables with elevation were also reported by Wilcox et al. (1957) and Yavuzatmaca (2020b). Electrical conductivity and elevation were also showed to cause the heterogeneities among three water basins in Turkey (Yavuzatmaca 2019). However, the non-significant differences of mean elevation values between lakes $(1876.9 \mathrm{~m})$ and streams $(1971.41 \mathrm{~m})$

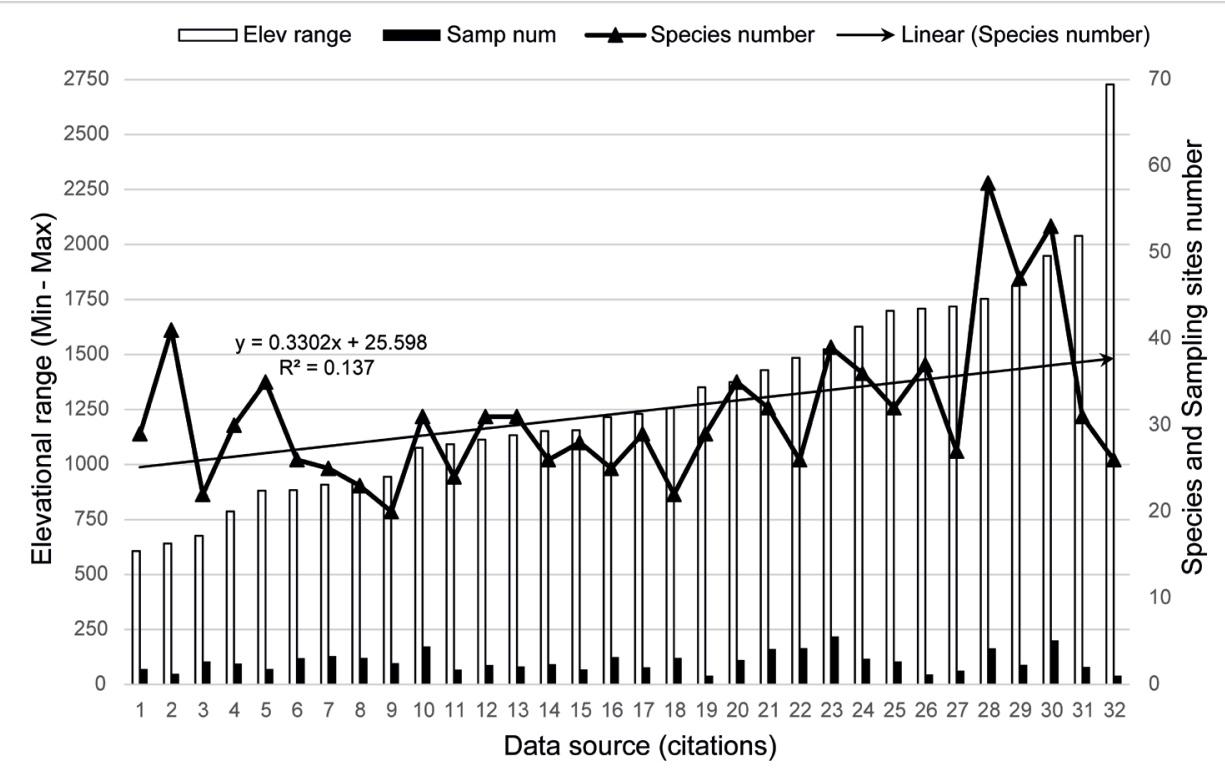

Fig. 4. Species richness across different elevational ranges (Elev range) and sampling sites (Samp num). Citations: 1 (Акреміr et al. 2016), 2 (Igliкоwsкa \& Nаміотко 2012), 3 (KüLKÖYLÜOĞLU et al. 2017a), 4 (KüLKÖYLÜOĞLU et al. 2012a), 5 (KüLKÖYLÜOĞLU et al. 2019a), 6 (Yavuzatmaca et al. 2015), 7 (KüLKÖYLÜOĞLu et al. 2016), 8 (KüLKÖYLÜOĞLU et al. 2018), 9 (KülкÖYLüoĞLu et al. 2021), 10 (UÇAK et al. 2014), 11 (АкDEмir et al. 2020), 12 (АкDEмir \& KülköylǘĞLu 2014), 13 (Yavuzatmaca et al. 2018), 14 (Yavuzatmaca et al. 2017a), 15 (Cusminsky et al. 2020), 16 (BAtmaz et al. 2020), 17 (KüLKÖYLÜOĞLu et al. 2012b), 18 (YAVUZATMACA et al. 2017b), 19 (the present study), 20 (KüLKÖYLÜOĞLU et al. 2019b), 21 (KüLKÖYLÜOĞLU et al. 2017b), 22 (KülKöylüoĞLu et al. 2012c), 23 (Pieri et al. 2020), 24 (DALGaKiran et al. 2020), 25 (KüLKÖYlüoĞLu et al. 2013), 26 (RAsouli et al. 2014), 27 (YavuZATMACA 2020a), 28 (KülKöylüoĞLu et al. 2020), 29 (VAn Der Meeren et al. 2010), 30 (Pieri et al. 2009), 31 (YAvuZATMACA 2019) and 32 (YavuZATMACA 2020b) 
indicated that elevation seems not to contribute significantly to the environmental variables' heterogeneity of both habitat types in the present study.

In contrast, the contribution of $\mathrm{EC}$ was more outstanding than those of $\mathrm{pH}$ and Tw. Alongside the $\mathrm{pH}, \mathrm{Tw}$, and $\mathrm{EC}^{\prime}$ s donation to the differences between lakes and streams, they were also pinpointed as the commonly found influential variables on the composition of ostracods among many previous studies compiled from literature by YavuzaTMACA (2019). Therefore, such differences among the habitats also affect their ostracod species composition because each species responds differently to these environmental variables.

The significant difference in the species composition between lakes and streams strengthens the statements mentioned above. Along with the differences in habitat types (KüLKöYLüOĞLU 2004), this could be due to the differences in $\mathrm{pH}$ and water temperature, because $\mathrm{pH}$ is an important variable affecting the calcification of ostracods (Higuti et al. 2010) when the life history and body size of them are influenced by water temperature (AGUILARAlberola \& Mesquita-Joanes 2014). In addition, 7 of the 8 species commonly found between the two habitat types (C. vidua, H. incongruens, I. bradyi, I. gibba, N. neglecta, P. albicans, and P. olivaceus) are well-known cosmopolitans (KüLKöylüoĞLu 2013, Yavuzatmaca 2019) except P. fallax. This result is expected because of the ecological plasticity of these species. For example, the well-known cosmopolitan species I. bradyi was found as an eudominant one in both habitat types. However, most of the species that cause the $70.81 \%$ of differences between the two habitat types are also cosmopolitan species $(L$. inopinata, I. bradyi, P. olivaceus, C. vidua, P. fallax, Cypria ophtalmica and N. neglecta). Similarly, Yavuzatmaca (2020a) most recently indicated cosmopolitan species ( $P$. olivaceus, $N$. neglecta, and $H$. incongruens) as the most important species contributing to the dissimilarity between lakes and streams. These results show that although cosmopolitan species do not have specific habitat preferences, they make significant contributions to local and regional biodiversity (KüLKÖYLÜOĞLU et al. 2012a) and the dis/similarities of habitats (YAVUZATMACA 2020a; the present study). Therefore, the importance of cosmopolitan species in diversity studies should not be underestimated, even though they are shown as the indicatives of the decrease in habitat quality.

Unlike species composition, species variations within lakes and streams did not significantly differ between both habitat types. However, greater species variability was reported among the replicates of lakes than streams based on the results obtained from MVDISP and SIMPER. Similarly, YavuZATMACA (2020b) stated that species variability of lakes was higher than streams, and much of the streams (64\%) in that study is 1st order streams when the rest are 2nd order. Also, Clarke et al. (2010) reported that the presence of high beta diversity of macroinvertebrates in the dendritic riverine landscape could be due to high heterogeneity among streams rather than head-water streams. In 
the present study, two-thirds of the streams are 1st order, and others are 2nd order. These streams start from high altitude and flow towards lower altitude by collecting water that allows one to think that their hydro morphological structures and environmental conditions are very similar to each other when compared to lakes. The reason is that snow and rainwater with low percolates into the soil directly flow to the stream bed at high elevations since the soil here is saturated with water and there is less transpiration (WiLcox et al. 1957). They also reported an increasing trend in the $\mathrm{pH}$ and salt contents of the soil profiles of the Mission Creek watershed from 6180 (1883.7 m asl.) to 1140 (347.5 m asl.) feet. Therefore, water bodies getting more seepage water from soil become more alkaline and saltier when compared with water bodies feeding directly with the surface flow. That explains why the average EC and $\mathrm{pH}$ values of lakes $(\mathrm{EC}=5863.75 \mu \mathrm{S} / \mathrm{cm}, \mathrm{pH}=8.79)$ are greater than streams $(\mathrm{EC}=177.89 \mu \mathrm{S} / \mathrm{cm}, \mathrm{pH}=8.28)$ in the present study. This result is because lake waters come from streams and seepage waters in a certain basin. All of them support the higher environmental heterogeneity and presence of many microhabitats in lakes compared to streams, and the $54.2 \%$ and $69.2 \%$ of species displaying a co-occurrence pattern in lakes and streams, respectively, are also strengthen this statement. This is because species exhibit co-occurrence pattern with the species having common environmental variable preferences. Thereby, while different microhabitats in the lakes allow species with different ecological preferences, the environmental similarity in the head water streams (1st and 2 nd orders) herein has enabled species with the same ecological preferences to be found together.

The positive correlation between species number and different habitat types as a statement of "Habitat diversity hypothesis" (Williams 1943) were supported by different studies dealing with ostracods (e.g., UÇAK et al. 2014, KüLKÖYLÜOĞLu et al. 2016). Also, Higuti et al. (2009) reported high species richness in lotic than lentic habitats because of higher environmental heterogeneity in lotic systems. As mentioned above, the lakes in the present study have higher environmental heterogeneity than streams that provide different microhabitats in lakes. Therefore, species richness and abundance between both habitat types are distinctly different, and the diversity index of lakes is higher than streams in the present study. Similarly, Yavuzatmaca (2020a) noted the presence of the higher Shannon diversity index values of lakes $\left(\mathrm{H}^{\prime}=2.16\right)$ than streams $\left(\mathrm{H}^{\prime}=1.62\right)$ when their species numbers equal (17 spp.). Another most recent study showed the occurrence of higher species number in lakes (18 spp.) than streams (12 spp.) when streams displayed a higher Shannon index value (YavuZatmaca 2020b).

On the other hand, Sмгтн et al. (2003) underlined that streams have high ostracod species diversity because they were the combined zone of groundwater discharge and recharge. LANSAC-TôHa et al. (2004) explained that the 
species richness of lotic habitats comes from lentic habitats since lotic habitats are showed as a connection among lentic habitats. So this may increase the availability of different habitats (or heterogeneity of streams), resulting in species numbers ascend. Most recently, KüLKÖYLÜOĞLU et al. (2021) declared that species numbers do not expose the significant difference between lotic and lentic habitats, and they also suggested the effectiveness of conditions in microhabitats rather than microhabitat types on freshwater ostracods. All these explain why species diversity in lakes is higher than in streams since environmental variables' heterogeneity caused many microhabitats.

Additionally, many microhabitats in lakes cause more species to emerge in lakes than streams, even with the same number of individuals (Table 1). Inasmuch as the presence of species with different ecological preferences in an environment prevents the dominance of certain species. Similarly, in the present study, the percentage of eudominant and dominant species in lakes $(12.5 \%)$ was smaller than half of the ratio in streams (30.8\%). In addition to the environmental variable's similarity, the low diversity in streams presented herein can be due to their size. This is because the size of streams starts to enlarge from 1st order streams to others (VANDER-Vorste et al. 2017).

Along with the size, their heterogeneity is caused by tributaries added to the stream bed from different water bodies, so species richness begins to escalate with the size of streams (VANNote et al. 1980). This finding is also supported by VICтоR et al. (1981), who stated the differences in the number of ostracods at the upstream and downstream stations on the same stream because of the drifting of the ostracod species by stream waters. This is because ostracods from different water bodies (or tributaries) are dragged by the current and moved towards the lower parts of the stream.

The number of species is in favour of benthonic ( 9 spp.) in the streams when the number of nektonic (13 spp.) and benthonic (11 spp.) species are not significantly different from each other in the lakes. These results support the previous studies. For example, Aкdemir et al. (2016) and Yavuzatmaca (2020a) emphasized the common occurrence of benthonic species in lotic and nektonic species in lentic habitats. However, KüLKÖYLÜOĞLU et al. (2021) recently found opposite results (10 nektonic and 5 benthonic species in lentic: 7 nektonic and 8 benthonic species in lotic habitats) from the present study. It is clearly understood from these studies, benthonic species have an advantage over nektonic in lotic habitats because of the advantage of crawling on the bottom to reduce the effect of flow and/or drift (Higuti et al. 2007). Therefore, they are commonly encountered with higher abundance in lotic habitats. This is also the case in the present study since 854 of the 898 individuals in streams belong to 9 benthonic species. Similarly, Aкдемir et al. (2016) registered the 1420 individuals belonging to 12 benthic species when 11 nektonic species are represented by 233 individuals in lotic habitats. DE CAMPos et al. (2018) declared the effect of 
aquatic macrophytes on the nektonic species because of their better dispersion ability rather than benthonic species at local scales in the 27 flood plain lakes in the Upper Paraná River floodplain (Brazil). This is because of the freely swimming ability of nektonic species where they found, flow regimes negatively affect their occurrence in lotic habitats, and so the number of benthonic species (9 spp.) herein are more than two times the number of nektonic species (4 spp.) in streams. Although nektonic species have an advantage over benthonic species in lentic habitats, benthonic species are also commonly encountered. For example, 13 nektonic and 11 benthonic species were represented by 363 and 560 individuals, respectively, in the present study. The higher abundance of benthonic species can be explained in two ways: i) nektonic species are actively moving and so the number of individuals corresponding to the sampling performed in $1 \mathrm{~m}^{2}$ area is low and ii) that is maybe due to the sampling technique, but standard sampling technique was used during the study. Therefore, the validity of the first reason seems to be more appropriate than the second. Thereby, the ecological preference of species is the primary factor YAVUZATMACA (2020a). However, it cannot tolerate morphologically (e.g., the negative effect of flow on the nektonic species) even if it tolerates ecologically. So the view as the preferences of nektonic species for lentic and benthonic species for lotic habitats are supported. When looking at the common species in both habitat types, most of them are well-known cosmopolitans with wide tolerance levels to ecological variables, and so they adapt to almost all aquatic bodies unless there is a morphological obstacle. In light of this information, if there is a suitable environment, species can be found in every habitat system regardless of whether they are nektonic or benthonic, as Hoff (1942) stated.

Similar to the present study, the effect of dissolved oxygen on the ostracod species composition in lakes was also reported by DüGEL et al. (2008) and Escríva et al. (2014). Besides, DE CAMpos et al. (2018) recorded dissolved oxygen as one of the crucial variables influencing ostracods in lakes in the Upper Paraná River floodplain (Brazil) along with the water temperature, electrical conductivity, and richness of macrophytes. In addition to the importance mentioned above of microalgae (as nutrients) and macrophytes at the littoral region (as shelter) for ostracod diversity, their densities in lakes affect the level of dissolved oxygen. KüLKöYLüOĞLU et al. (2018) recorded the strong positive relationships between total species numbers and dissolved oxygen. Its importance is also strengthened by finding a significantly positive correlation of Shannon index value with dissolved oxygen in lakes, but this correlation is negative with $\mathrm{pH}$. Ruiz et al. (2013) said that freshwater ostracods generally occur in alkaline or slightly acidic waters, and a $\mathrm{pH}$ range from 7 to 9 was shown as the common range for many species. In the present study, a range from 7.12 to 10.1 with a mean equal to 8.76 was found for lakes bearing living ostracods. This alkaline mean value may explain this negative correlation 
because most of the species in lakes did not show a close relationship with $\mathrm{pH}$ except L. inopinata. Other species in lakes also show different relationships to environmental variables according to their optimum and tolerance levels. The situation is similar in streams. For example, S. fischeri was located on the opposite side of $\mathrm{pH}$ with the lowest $\mathrm{pH}$ optimum value. The close relationship of $S$. fisheri and N. neglecta with dissolved oxygen endorsed the indicator potential of them for high dissolved oxygen (Yavuzatmaca 2020a). Potamocypris similis had a negative relationship with electrical conductivity, and it is one of the species that had the lowest optimum and tolerance values among species.

The low electrical conductivity in the streams seems a limiting factor, and so it was found as the only influential environmental variable that controlled the species composition in streams. SMith et al. (2003) pointed out the strong relationship of stream species with ionic composition. Thus, salinity related to EC was indicated as a key factor for species distribution of ostracods (Ruiz et al. 2013). As known, conductivity in water is a combination of negatively (e.g., chloride, sulfate) and positively (e.g., calcium, magnesium) charged inorganic dissolved solids. Alongside the osmoregulation effect of ion composition, ions like calcium and magnesium in ostracod carapaces come from wasters where they were found (Kesling 1951, Palaciost-Fest \& Dettmann 2001). This information suggests the importance of $\mathrm{EC}$ for ostracod species composition in the streams.

Finally, significant species composition was found between both habitat types due to the environmental heterogeneity in lakes and similarity in headwater streams herein, and the variation in species composition in lakes is larger than in streams. It was seen that ostracods are mostly tied to dissolved oxygen and electrical conductivity in lakes and streams, respectively. There was no difference in the frequency occurrence of benthonic and nektonic species in lakes, while benthonic densely occurs in streams. In general, albeit a little positive relationship was observed between elevational range and ostracod species richness. This indicated that elevation range as a regional factor might influence the species composition as well as species distribution. Accordingly, determining regional and local factors based on habitats will help us easily interpret ostracod species diversity, so the number of such studies should increase.

Acknowledgements - The valuable comments of Prof. Dr. Okan Külköylüoğlu (Bolu Abant İzzet Baysal University, Turkey) and Prof. Dr. Abuzer Çelekli (Gaziantep University, Turkey) on the first draft are gratefully acknowledged. I am thankful to Mrs Mary Theresa Dorothy Williams (North Carolina State University) for her help with English. I thank to Mrs Filiz Batmaz for her helps in the laboratory. I am greatly indebted to two anonymous reviewers for their invaluable comments and suggestions. 


\section{REFERENCES}

Aguilar-Alberola, J. A. \& Mesquita-Joanes, F. (2014): Breaking the temperature-size rule: thermal effects on growth, development and fecundity of a crustacean from temporary waters. - Journal of Thermal Biology 42: 15-24.

https://doi.org/10.1016/j.jtherbio.2014.02.016

AкDEмir, D. \& KüLKöylüoĞLU, O. (2014): Preliminary study on distribution, diversity and ecological characteristics of nonmarine Ostracoda (Crustacea) from Erzincan region (Turkey). - Turkish Journal of Zoology 38: 421-431. https://doi.org/10.3906/zoo-1301-16

Aкdemir, D., KülköylüoĞLU, O., Yavuzatmaca, M. \& SARI, N. (2016): Freshwater ostracods (Crustacea) of Gaziantep (Turkey) and their habitat preferences according to movement ability. - Fundamental and Applied Limnology 187(4): 307-314. https://doi.org/10.1127/fal/2016/0665

Akdemir, D., KülköylüoĞlu, O., Yavuzatmaca, M., Tanyeri, M., Gürer, M., Alper, A., Dere, Ş., Çelen, E., Yilmaz, O. \& Özcan, G. (2020): Ecological characteristics and habitat preferences of Ostracoda (Crustacea) with a new bisexual population record (Muğla, Turkey). - Applied Ecology and Environmental Research 18(1): 1471-1487. https://doi.org/10.15666/aeer/1801_14711487

Anderson, M. J. (2001): A new method for nonparametric multivariate analysis of variance. - Austral Ecology 26: 32-46. https://doi.org/10.1111/j.1442-9993.2001.01070.pp.x

Anderson, M. J. (2006): Distance-based tests for homogeneity of multivariate dispersions. - Biometrics 62: 245-253. https://doi.org/10.1111/j.1541-0420.2005.00440.x

Anderson, M. J., Ellingsen, K. E. \& McArdle, B. H. (2006): Multivariate dispersion as a measure of beta diversity. - Ecology Letters 9: 683-693. https://doi.org/10.1111/j.1461-0248.2006.00926.x

Batmaz, F., KülköylüoĞlu, O., Aкdemir, D. \& Yavuzatmaca, M. (2020): Effective roles of ecological factors on nonmarine Ostracoda (Crustacea) in shallow waters of Malatya (Turkey). - Ecological Research 35: 511-523. https://doi.org/10.1111/1440-1703.12120

Clarke, K. R. \& Gorley, R. N. (2015): PRIMER v7: User Manual/Tutorial. - PRIMER-E, Plymouth.

Clarke, A., MacNally, R., Bond, N. R. \& Lake, P. S. (2010): Conserving macroinvertebrate diversity in headwater streams: the importance of knowing the relative contributions of $\alpha$ and $\beta$ diversity. - Diversity and Distributions 16: 725-736. https://doi.org/10.1111/j.1472-4642.2010.00692.x

Clarke, K. R. \& Warwick, R. M. (2001): Change in marine communities: An approach to statistical analysis and interpretation. - PRIMER-E, Plymouth.

Climate-Data.org (2020): https://tr.climate-data.org/asya/tuerkiye-67/ [Accessed 05.06.2020]

Cusminsky, G., Coviaga, C., Ramos, L., Pérez, A. P., Schwalb, A., Markgraf, V., Ariztegui, D., Viehberg, F. \& Alperin, M. (2020): Characterizing ecoregions in Argentinian Patagonia using extant continental ostracods. - Anais da Academia Brasileira de Ciências 92(Suppl. 2): e20190459. https://doi.org/10.1590/0001-3765202020190459

Dalgakiran, E., KülköylüoĞlu, O., Yavuzatmaca, M. \& Akdemir, D. (2020): Correlational analyses of the relationships between altitude and carapace size of Ostracoda (Crustacea). - Annales de Limnologie - International Journal of Limnology 56: 2. https://doi.org/10.1051/limn/2019025

de Campos, R., Lansac-Tôha, F. M., da Conceição, E. D., Martens, K. \& Higuti, J. (2018): Factors affecting the metacommunity structure of periphytic ostracods (Crustacea, Ostracoda): a deconstruction approach based on biological traits. - Aquatic Sciences 80: 16. https://doi.org/10.1007/s00027-018-0567-2 
Dehling, D. M., Hof, C., Brändle, M. \& Brandl, R. (2010): Habitat availability does not explain the species richness patterns of European lentic and lotic freshwater animals. Journal of Biogeography 37: 1919-1926. https://doi.org/10.1111/j.1365-2699.2010.02347.x

Dunn, N. R., O’Brien, L. K., Burridge, C. P. \& Closs, G. P. (2020): Morphological convergence and divergence in Galaxias fishes in lentic and lotic habitats. - Diversity 12: 183. https://doi.org/10.3390/d12050183

Dügel, M., KüLкÖYLÜOĞLU, O. \& Kilıç, M. (2008): Species assemblages and habitat preferences of Ostracoda (Crustacea) in Lake Abant (Bolu, Turkey). - The Belgian Journal of Zoology 138(1): 50-59.

Escríva, A., Rueda, J., Armengol, X. \& Mesquita-Joanes, F. (2014): Artificial dam lakes as suitable habitats for exotic invertebrates: Ostracoda ecology and distribution in reservoirs of the Eastern Iberian Peninsula. - Knowledge and Management of Aquatic Ecocystems 412: 09. https://doi.org/10.1051/kmae/2013091

Hammer, Ø., Harper, D. A. \& Ryan, P. D. (2001): PAST: Paleontological statistics software package for education and data analysis. - Palaeontologia Electronica 4(1): 9.

Higuti, J., Declerck, S. A. J., Lansac-Tôha, F. A., Velho, L. F. M. \& Martens, K. (2010): Variation in ostracod (Crustacea, Ostracoda) communities in the alluvial valley of the upper Paraná river (Brazil) in relation to substrate. - Hydrobiologia 644: 261-278. https://doi.org/10.1007/s10750-010-0122-1

Higuti, J., Lansac-Tôha, F. A., Velho, L. F. M. \& Martens, K. (2009): Biodiversity of nonmarine ostracods (Crustacea, Ostracoda) in the alluvial valley of the upper Paraná river. - Brazilian Journal of Biology 69: 661-668. https://doi.org/10.1590/S1519-69842009000300020

Higuti, J., Velho, L. F. M., Lansac-Tôha, A. \& Martens, K. (2007): Pleuston communities are buffered from regional flood pulses: the example of ostracods in the Paraná River floodplain, Brazil. - Freshwater Biology 52: 1930-1943. https://doi.org/10.1111/j.1365-2427.2007.01821.x

Hof, C., BRÄNDle, M. \& BRANDL, R. (2008): Latitudinal variation of diversity in European freshwater animals is not concordant across habitat types. - Global Ecology and Biogeography 17(4): 539-546. https://doi.org/10.1111/j.1466-8238.2008.00394.x

Hoff, C. C. (1942): The ostracods of Illinois, their biology and taxonomy. - Illinois Biological Monographs 19(1-2): 1-196. https://doi.org/10.5962/bhl.title.50126

Iglikowska, A. \& Naмiotко, T. (2012): The impact of environmental factors on diversity of Ostracoda in freshwater habitats of subarctic and temperate Europe. - Annales Zoologici Fennici 49: 193-218. https://doi.org/10.5735/086.049.0401

JugGins, S. (2003): Software for ecological and palaeoecological data analysis and visualization - C2 User Guide. - University of Newcastle, Newcastle-upon-Tyne.

Karanovic, I. (2012): Recent freshwater ostracods of the world. - Springer, Heidelberg. https://doi.org/10.1007/978-3-642-21810-1

Kesling, R. V. (1951): The morphology of ostracod molt stages. - Illinois Biological Monographs 21: 1-126. https://doi.org/10.5962/bhl.title.50392

KüLKöYLÜOĞLU, O. (2004): On the usage of ostracods (Crustacea) as bioindicator species in different aquatic habitats in the Bolu region, Turkey. - Ecological Indicators 4: 139-147. https://doi.org/10.1016/j.ecolind.2004.01.004

KüLKÖYLÜOĞLU, O. (2013): Diversity, distribution and ecology of non-marine Ostracoda (Crustacea) in Turkey: application of pseudorichness and cosmoecious species concepts. - Recent Research Development in Ecology 4: 1-18. 
KülköylüoĞlu, O., Akdemir, D., Sari, N., Yavuzatmaca, M., Oral, C. \& Başak, E. (2013): Distribution and ecology of Ostracoda (Crustacea) from troughs in Turkey. - Turkish Journal of Zoology 37: 277-287. https://doi.org/10.3906/zoo-1205-17

KülköylüoĞlu, O., Akdemir, D., Yavuzatmaca, M., Çelen, E., Dere, Ş. \& Dalkiran, N. (2019): Do reproductive modes and swimming ability influence occurrence of nonmarine ostracod (Crustacea) species among aquatic habitats? - Zoological Science 36(6): 511-520. https://doi.org/10.2108/zs180193

KüLKÖYLÜOĞLU, O., SARI, N. \& AKDemir, D. (2012b): Distribution and ecological requirements of ostracods (Crustacea) at high altitudinal ranges in Northeastern Van (Turkey). - Annales de Limnologie - International Journal of Limnology 48: 39-51. https://doi.org/10.1051/limn/2011060

KülköylüoĞLu, O., SARi, N., Akdemir, D., Yavuzatmaca, M. \& Altinbă̆, C. (2012c): Distribution of sexual and asexual Ostracoda (Crustacea) from different altitudinal ranges in the Ordu region of Turkey: Testing the Rapoport rule. - High Altitude Medicine $\mathcal{E}$ Biology 13(2): 126-136. https://doi.org/10.1089/ham.2011.1111

KülköylüoĞlu, O., Yavuzatmaca, M. \& Akdemir, D. (2021): Occurrence patterns, photoperiod and dispersion ability of the non-marine Ostracoda (Crustacea) in shallow waters. - Turkish Journal of Fisheries and Aquatic Sciences 21(2): 73-85. https://doi.org/10.4194/1303-2712-v21_2_03

KülköylüoĞlu, O., Yavuzatmaca, M., Akdemir, D. \& Sari, N. (2012a): Distribution and local species diversity of freshwater Ostracoda in relation to habitat in the KahramanmaraşProvinceofTurkey.-InternationalReviewofHydrobiology 97(4):247-261. https://doi.org/10.1002/iroh.201111490

KülköylüoĞlu, O., Yavuzatmaca, M., Akdemir, D., Yilmaz, O., Çelen, E., Dere, Ş. \& DALKIRAN, N. (2019a): Correlational patterns of species diversity, swimming ability and ecological tolerance of non-marine ostracoda (Crustacea) with different reproductive modes in shallow water bodies of Ağrı region (Turkey). - Journal of Freshwater Ecology 34(1): 151-165. https://doi.org/10.1080/02705060.2019.1576551

KülköylüoĞlu, O., Yavuzatmaca, M., Çelen, E., Akdemir, D. \& Dalkiran, N. (2018): Ecological classification of the freshwater Ostracoda (Crustacea) based on physicochemical properties of waters and habitat preferences. - Annales de Limnologie - International Journal of Limnology 54: 26. https://doi.org/10.1051/limn/2018017

KülköylüoĞlu, O., Yavuzatmaca, M., Sari, N. \& Akdemir, D. (2016): Elevational distribution and species diversity of freshwater Ostracoda (Crustacea) in Çankırı region (Turkey). - Journal of Freshwater Ecology 31(2): 219-230.

https://doi.org/10.1080/02705060.2015.1050467

KülköYlüoĞLu, O., Yavuzatmaca, M., TAnYeRi, M. \& Yilmaz, O. (2017a): Ostracoda (Crustacea) species composition and environmental correlates in different aquatic habitats of the Zonguldak and Bartın regions (Turkey). - Turkish Journal of Zoology 41: 686-695. https://doi.org/10.3906/zoo-1512-36

KülköylüoĞLu, O., Yavuzatmaca, M. \& Yilmaz, O. (2020): Ecology and distribution of ostracods in Mardin and Muş provinces in Turkey. - Biologia 75(11): 1855-1870. https://doi.org/10.2478/s11756-020-00439-5

KülköylüoĞLu, O., Yilmaz, S. \& Yavuzatmaca, M. (2017b): Comparison of Ostracoda (Crustacea) species diversity, distribution and ecological characteristics among habitat types. - Fundamental and Applied Limnology 190(1): 63-86.

https://doi.org/10.1127/fal/2017/0872 
Lansac-Tôha, F. A., Bonecker, C. C. \& Velho, L. F. M. (2004): Composition, species richness and abundance of the zooplankton community. Pp. 145-190. In: Thomaz, S. M., Agostinho, A. A. \& Hahn, N. S. (eds): The Upper Paraná River and its floodplain: Physical aspects, ecology and conservation. - Backhuys Publishers, Leiden.

Lottig, N. R., Stanley, E. H., Hanson, P. C. \& Kratz, T. K. (2011): Comparison of regional stream and lake chemistry: Differences, similarities, and potential drivers. - Limnology and Oceanography 56(5): 1551-1562. https://doi.org/10.4319/lo.2011.56.5.1551

Marmonier, P., Bodergat, A. M. \& Dolédec, S. (1994): Theoretical habitat templets, species traits, and species richness: ostracods (Crustacea) in the Upper Rhône River and its floodplain. - Freshwater Biology 31: 341-355. https://doi.org/10.1111/j.1365-2427.1994.tb01745.x

McKenzie, K. G. \& Moroni, A. (1986): Man as an agent of crustacean passive dispersal via useful plants: exemplified by Ostracoda Ospiti esteri of the Italian ricefields ecosystem: and implications arising therefrom. - Journal of Crustacean Biology 6(2): 181-198. https://doi.org/10.1163/193724086X00019

Meisch, C. (2000): Freshwater Ostracoda of Western and Central Europe (Süswasserfauna von Mitteleuropa), Vol. 8. - Spektrum Akademischer Verlag, Heidelberg:, I-xii, 522 pp.

Mishra, G. P. \& YAdAV, A. K. (1978): A comparative study of physicochemical characteristics of river and lake water in Central India. - Hydrobiologia 59(3): 275-278. https://doi.org/10.1007/BF00036506

Palacios-Fest, M. R. \& Dettman, D. L. (2001): Temperature controls monthly variation in ostracode valve $\mathrm{Mg} / \mathrm{Ca}$ : Cypridopsis vidua from a small lake in Sonora, Mexico. - Geochimica et Cosmochimica Acta 65: 2499-2508. https://doi.org/10.1016/S0016-7037(01)00602-0

Pieri, V., Marrone, F., Martens, K. \& Rossetti, G. (2020): An updated checklist of recent ostracods (Crustacea: Ostracoda) from inland waters of Sicily and adjacent small islands with notes on their distribution and ecology. - The European Zoological Journal 87(1): 714-740, https://doi.org/10.1080/24750263.2020.1839581

Pieri, V., Martens, K., Stoch, F. \& Rossetti, G. (2009): Distribution and ecology of non-marine ostracods (Crustacea, Ostracoda) from Friuli Venezia Giulia (NE Italy). - Journal of Limnology 68(1): 1-15. https://doi.org/10.4081/jlimnol.2009.1

Rasouli, H., Aygen, C. \& KülкöylüoĞLu, O. (2014): Contribution to the freshwater Ostracoda (Crustacea) fauna of Turkey: Distribution and ecological notes. - Turkish Journal of Fisheries and Aquatic Sciences 20: 11-20. https://doi.org/10.4194/1303-2712-v14_1_02

Rомвасн, R. (1999): Auswirkungen verschiedener Formen der Bewirtschaftung von Halbtrockenrasen auf die Zikaden am Beispiel der Enzian-Schillergras-Rasen (Gentiano-Koelerietum) der Nordeifel. - Dissertation. Math. Naturwiss. Fakultaet, Rheinische Friedrich-WilhelmsUniversitaet Bonn. URL; http://www.punct.de/science/Diss11c.pdf

Ruiz, F., Abad, M., Bodergat, A. M., Carbonel, P., Rodríguez-Lázaro, J., González-Regalado, M. L., Toscano, A., García, E. X. \& Prenda, J. (2013): Freshwater ostracods as environmental tracers. - International Journal of Environmental Science and Technology 10: 1115-1128. https://doi.org/10.1007/s13762-013-0249-5

Seaby, R. M. \& Henderson, P. A. (2006): Species diversity and richness version 4. Pisces. - Conservation Ltd., Lymington, England.

Smith, A., Davis, J., Palmer, D., Forester, R. \& Curry, B. (2003): Ostracodes as hydrologic indicators in springs, streams and wetlands: A tool for environmental and paleoenvironmental assessment. - The Paleontological Society Papers 9: 203-222. https://doi.org/10.1017/S1089332600002217 
Strahler, A. N. (1957): Quantitative analysis of watershed geomorphology. - Transactions of the American Geophysical Union 38: 913-920. https://doi.org/10.1029/TR038i006p00913

TER BrAak, C. J. F. \& S SMILAUer, P. (2002): CANOCO Reference Manual and CanoDraw for Windows User's Guide: Software for Canonical Community Ordination (version 4.5).

UÇAK, S., KüLKöYlüOĞLU, O., АкDEMir, D. \& BAşAK, E. (2014): Distribution, diversity and ecological characteristics of freshwater Ostracoda (Crustacea) in shallow aquatic bodies of the Ankara region, Turkey. - Wetlands 34: 309-324. https://doi.org/10.1007/s13157-013-0499-5

Van der Meeren, T., Almendinger, J. E., Ito, E. \& Martens, K. (2010): The ecology of ostracodes (Ostracoda, Crustacea) in western Mongolia. - Hydrobiologia 641: 253-273. https://doi.org/10.1007/s10750-010-0089-y

Vander-Vorste, R., McElmurray, P., Bell, S., Eliason, K. M. \& Brown, B. L. (2017): Does stream size really explain biodiversity patterns in lotic systems? A call for mechanistic explanations. - Diversity 9(3): 26. https://doi.org/10.3390/d9030026

Vannote, R. L., Minshall, G. W., Cummins, K. W., Sedell, J. R. \& Cushing, D. H. (1980): The river continuum concept. - Canadian Journal of Fisheries and Aquatic Sciences 37: 130-137. https://doi.org/10.1139/f80-017

Victor, R., Dance, K. W. \& Hynes, H. B. N. (1981): Drift of ostracod crustaceans in adjacent intermittent and permanent streams. - Hydrobiologia 80(3): 219-223. https://doi.org/10.1007/BF00018360

WARWICK, R. M. \& CLARKE, K. R. (1993): Increased variability as a symptom of stress in marine communities. - Journal of Experimental Marine Biology and Ecology 172: 215-226. https://doi.org/10.1016/0022-0981(93)90098-9

Wetzel, R. G. (2001): Limnology: lake and river ecosystems. - Academic Press, Elsevier Science, USA.

Wilcox, J. C., Holland, W. D. \& McDougald, J. M. (1957): Relation of elevation of a mountain streams to reaction and soil content of water and soil. - Canadian Journal of Soil Science 37: 11-20. https://doi.org/10.4141/cjss57-002

Williams, C. B. (1943): Area and number of species. - Nature 152: 264-267. https://doi.org/10.1038/152264a0

YavuzatmacA, M. (2019): Comparative analyses of non-marine Ostracods (Crustacea) among water basins in Turkey. - Acta Zoologica Academiae Scientiarum Hungaricae 65(3): 269-297. https://doi.org/10.17109/AZH.65.3.269.2019

Yavuzatmaca, M. (2020a): Species assemblages of Ostracoda (Crustacea) from west-site of Turkey: their indicator potential for lotic and lentic habitats. - Biologia 75(12): 23012314. https://doi.org/10.2478/s11756-020-00494-y.

Yavuzatmaca, M. (2020b): Diversity analyses of nonmarine ostracods (Crustacea, Ostracoda) in streams and lakes in Turkey. - Turkish Journal of Zoology 44(6): 519-530. https://doi.org/10.3906/zoo-2005-20

Yavuzatmaca, M., KülköylüoĞLu, O., Акdemir, D. \& Çelen, E. (2018): On the relationship between the occurrence of ostracod species and elevation in Sakarya province, Turkey. - Acta Zoologica Academiae Scientiarum Hungaricae 64(4): 329-354. https://doi.org/10.17109/AZH.64.4.329.2018

Yavuzatmaca, M., KüLKöylüoĞLu, O. \& Yilmaz, O. (2015): Distributional patterns of nonmarine Ostracoda (Crustacea) in Adiyaman Province (Turkey). - Annales de Limnologie - International Journal of Limnology 51: 101-113. https://doi.org/10.1051/limn/2015005 
Yavuzatmaca, M., KülköylüoĞLu, O. \& Yilmaz, O. (2017b): Estimating distributional patterns of non-marine Ostracoda (Crustacea) and habitat suitability in the Burdur province (Turkey). - Limnologica 62: 19-33. https://doi.org/10.1016/j.limno.2016.09.006

Yavuzatmaca, M., KülköylüoĞLu, O., Yılmaz, O. \& Aкdemir, D. (2017a): On the relationship of ostracod species (Crustacea) to shallow water ion and sediment phosphate concentration across different elevational range (Sinop, Turkey). - Turkish Journal of Fisheries and Aquatic Sciences 17: 1333-1346. https://doi.org/10.4194/1303-2712-v17_6_40

Received May 15, 2021, accepted August 5, 2021, published November 19, 2021

\section{SUPPLEMENTARY MATERIALS}

Table S1. Station code, provinces where they found, and coordinates of lakes and streams sampled in the present study. Lowercase $a, b$ and $c$ display the multiple samplings in a lake.

\begin{tabular}{|c|c|c|c|}
\hline Station code & Habitat type & Province & Coordinates \\
\hline L1a & Lake & Van & $38^{\circ} 29^{\prime} 45.29^{\prime \prime} \mathrm{N}, 43^{\circ} 55^{\prime} 27.73^{\prime \prime} \mathrm{E}$ \\
\hline $\mathrm{L} 1 \mathrm{~b}$ & Lake & Van & $38^{\circ} 29^{\prime} 26.71^{\prime \prime} \mathrm{N}, 43^{\circ} 54^{\prime} 50.24^{\prime \prime} \mathrm{E}$ \\
\hline L1c & Lake & Van & $38^{\circ} 28^{\prime} 32.74^{\prime \prime} \mathrm{N}, 43^{\circ} 55^{\prime} 05.08^{\prime \prime} \mathrm{E}$ \\
\hline $\mathrm{L} 2$ & Lake & Van & $38^{\circ} 37^{\prime} 59.32^{\prime \prime} \mathrm{N}, 43^{\circ} 36^{\prime} 20.98^{\prime \prime} \mathrm{E}$ \\
\hline L3 & Lake & Van & $38^{\circ} 43^{\prime} 44.80^{\prime \prime} \mathrm{N}, 43^{\circ} 33^{\prime} 57.70^{\prime \prime} \mathrm{E}$ \\
\hline $\mathrm{L} 4$ & Lake & Bitlis & $38^{\circ} 48^{\prime} 53.33^{\prime \prime} \mathrm{N}, 43^{\circ} 00^{\prime} 35.37^{\prime \prime} \mathrm{E}$ \\
\hline $\mathrm{L} 5 \mathrm{a}$ & Lake & Van & $38^{\circ} 25^{\prime} 34.64^{\prime \prime} \mathrm{N}, 43^{\circ} 15^{\prime} 50.26^{\prime \prime} \mathrm{E}$ \\
\hline $\mathrm{L} 5 \mathrm{~b}$ & Lake & Bitlis & $38^{\circ} 45^{\prime} 15.29^{\prime \prime} \mathrm{N}, 42^{\circ} 30^{\prime} 28.59^{\prime \prime} \mathrm{E}$ \\
\hline L6a & Lake & Bitlis & $38^{\circ} 50^{\prime} 13.63^{\prime \prime} \mathrm{N}, 42^{\circ} 16^{\prime} 10.20^{\prime \prime} \mathrm{E}$ \\
\hline L6b & Lake & Bitlis & $38^{\circ} 50^{\prime} 56.16^{\prime \prime} \mathrm{N}, 42^{\circ} 20^{\prime} 34.53^{\prime \prime} \mathrm{E}$ \\
\hline L7 & Lake & Kars & $40^{\circ} 46^{\prime} 24.40^{\prime \prime} \mathrm{N}, 43^{\circ} 00^{\prime} 34.60^{\prime \prime} \mathrm{E}$ \\
\hline L8 & Lake & Kars & $40^{\circ} 59^{\prime} 14.88^{\prime \prime} \mathrm{N}, 43^{\circ} 17^{\prime} 37.98^{\prime \prime} \mathrm{E}$ \\
\hline L9 & Lake & Ardahan & $41^{\circ} 12^{\prime} 16.82^{\prime \prime} \mathrm{N}, 43^{\circ} 11^{\prime} 12.84^{\prime \prime} \mathrm{E}$ \\
\hline L10 & Lake & Artvin & $41^{\circ} 23^{\prime} 04.77^{\prime \prime} \mathrm{N}, 41^{\circ} 51^{\prime} 12.67^{\prime \prime} \mathrm{E}$ \\
\hline L11 & Lake & Artvin & $41^{\circ} 25^{\prime} 09.91^{\prime \prime} \mathrm{N}, 42^{\circ} 27^{\prime} 06.18^{\prime \prime} \mathrm{E}$ \\
\hline L12 & Lake & Artvin & $41^{\circ} 24^{\prime} 29.59^{\prime \prime} \mathrm{N}, 42^{\circ} 30^{\prime} 39.76^{\prime \prime} \mathrm{E}$ \\
\hline L13 & Lake & Artvin & $41^{\circ} 21^{\prime} 57.08^{\prime \prime} \mathrm{N}, 42^{\circ} 30^{\prime} 16.85^{\prime \prime} \mathrm{E}$ \\
\hline L14 & Lake & Artvin & $41^{\circ} 17^{\prime} 16.15^{\prime \prime} \mathrm{N}, 42^{\circ} 27^{\prime} 39.02^{\prime \prime} \mathrm{E}$ \\
\hline L15 & Lake & Erzurum & $40^{\circ} 55^{\prime} 30.35^{\prime \prime} \mathrm{N}, 42^{\circ} 11^{\prime} 44.93^{\prime \prime} \mathrm{E}$ \\
\hline L16 & Lake & Erzurum & $40^{\circ} 39^{\prime} 21.12^{\prime \prime} \mathrm{N}, 41^{\circ} 39^{\prime} 29.16^{\prime \prime} \mathrm{E}$ \\
\hline S1 & Stream & Van & $38^{\circ} 23^{\prime} 31.34^{\prime \prime} \mathrm{N}, 43^{\circ} 34^{\prime} 55.20^{\prime \prime} \mathrm{E}$ \\
\hline $\mathrm{S} 2$ & Stream & Van & $38^{\circ} 26^{\prime} 27.38^{\prime \prime} \mathrm{N}, 43^{\circ} 32^{\prime} 49.34^{\prime \prime} \mathrm{E}$ \\
\hline
\end{tabular}


Table S1 (continued)

\begin{tabular}{|c|c|c|c|}
\hline Station code & Habitat type & Province & Coordinates \\
\hline S3 & Stream & Van & $38^{\circ} 25^{\prime} 59.74^{\prime \prime} \mathrm{N}, 43^{\circ} 30^{\prime} 31.90^{\prime \prime} \mathrm{E}$ \\
\hline S4 & Stream & Van & $38^{\circ} 26^{\prime} 0.276^{\prime \prime} \mathrm{N}, 43^{\circ} 27^{\prime} 18.50^{\prime \prime} \mathrm{E}$ \\
\hline S5 & Stream & Erzurum & $39^{\circ} 39^{\prime} 16.60^{\prime \prime} \mathrm{N}, 41^{\circ} 19^{\prime} 38.82^{\prime \prime} \mathrm{E}$ \\
\hline S6 & Stream & Erzurum & $39^{\circ} 44^{\prime} 59.03^{\prime \prime} \mathrm{N}, 41^{\circ} 32^{\prime} 8.556^{\prime \prime} \mathrm{E}$ \\
\hline S7 & Stream & Erzurum & $39^{\circ} 35^{\prime} 3.120^{\prime \prime} \mathrm{N}, 41^{\circ} 38^{\prime} 55.97^{\prime \prime} \mathrm{E}$ \\
\hline S8 & Stream & Erzurum & $39^{\circ} 53^{\prime} 10.57^{\prime \prime} \mathrm{N}, 41^{\circ} 43^{\prime} 28.24^{\prime \prime} \mathrm{E}$ \\
\hline S9 & Stream & Erzurum & $39^{\circ} 50^{\prime} 43.87^{\prime \prime} \mathrm{N}, 41^{\circ} 44^{\prime} 23.75^{\prime \prime} \mathrm{E}$ \\
\hline S10 & Stream & Erzurum & $40^{\circ} 02^{\prime} 57.44^{\prime \prime} \mathrm{N}, 41^{\circ} 37^{\prime} 28.02^{\prime \prime} \mathrm{E}$ \\
\hline S11 & Stream & Kars & $40^{\circ} 18^{\prime} 39.89^{\prime \prime} \mathrm{N}, 42^{\circ} 10^{\prime} 45.48^{\prime \prime} \mathrm{E}$ \\
\hline S12 & Stream & Kars & $40^{\circ} 10^{\prime} 45.48^{\prime \prime} \mathrm{N}, 42^{\circ} 36^{\prime} 10.69^{\prime \prime} \mathrm{E}$ \\
\hline S13 & Stream & Kars & $40^{\circ} 12^{\prime} 40.61^{\prime \prime} \mathrm{N}, 42^{\circ} 41^{\prime} 27.38^{\prime \prime} \mathrm{E}$ \\
\hline S14 & Stream & Kars & $41^{\circ} 03^{\prime} 15.70^{\prime \prime} \mathrm{N}, 43^{\circ} 15^{\prime} 13.43^{\prime \prime} \mathrm{E}$ \\
\hline S15 & Stream & Ardahan & $41^{\circ} 31^{\prime} 50.81^{\prime \prime} \mathrm{N}, 42^{\circ} 37^{\prime} 13.87^{\prime \prime} \mathrm{E}$ \\
\hline S16 & Stream & Ardahan & $41^{\circ} 34^{\prime} 19.34^{\prime \prime} \mathrm{N}, 42^{\circ} 40^{\prime} 19.99^{\prime \prime} \mathrm{E}$ \\
\hline S17 & Stream & Ardahan & $41^{\circ} 34^{\prime} 12.86^{\prime \prime} \mathrm{N}, 42^{\circ} 40^{\prime} 17.26^{\prime \prime} \mathrm{E}$ \\
\hline S18 & Stream & Artvin & $41^{\circ} 20^{\prime} 34.01^{\prime \prime} \mathrm{N}, 42^{\circ} 29^{\prime} 32.53^{\prime \prime} \mathrm{E}$ \\
\hline S19 & Stream & Artvin & $41^{\circ} 23^{\prime} 56.94^{\prime \prime} \mathrm{N}, 42^{\circ} 09^{\prime} 59.11^{\prime \prime} \mathrm{E}$ \\
\hline S20 & Stream & Erzurum & $40^{\circ} 40^{\prime} 7.07^{\prime \prime} \mathrm{N}, 40^{\circ} 59^{\prime} 27.67^{\prime \prime} \mathrm{E}$ \\
\hline S21 & Stream & Erzurum & $40^{\circ} 39^{\prime} 45.79^{\prime \prime} \mathrm{N}, 40^{\circ} 58^{\prime} 14.84^{\prime \prime} \mathrm{E}$ \\
\hline S22 & Stream & Erzurum & $40^{\circ} 28^{\prime} 50.41^{\prime \prime} \mathrm{N}, 40^{\circ} 41^{\prime} 5.71^{\prime \prime} \mathrm{E}$ \\
\hline S23 & Stream & Erzurum & $40^{\circ} 31^{\prime} 11.39^{\prime \prime} \mathrm{N}, 40^{\circ} 38^{\prime} 58.74^{\prime \prime} \mathrm{E}$ \\
\hline S24 & Stream & Erzurum & $40^{\circ} 17^{\prime} 07.04^{\prime \prime} \mathrm{N}, 41^{\circ} 00^{\prime} 18.68^{\prime \prime} \mathrm{E}$ \\
\hline
\end{tabular}

Table S2

(digital supplement only; DOI 10.17109/AZH.67.4.377.TS2.2021) 
Table S3. Summary tables of RDA for lakes and streams. * indicates DCA results.

\begin{tabular}{llccccc}
\hline & Axes & 1 & 2 & 3 & 4 & Total variance \\
\hline Lakes & Eigenvalues & 0.306 & 0.081 & 0.041 & 0.004 & 1 \\
& *Lengths of gradient & 0 & 2.70 & 0.87 & 2.51 & \\
& Species-environment correlations & 0.79 & 0.555 & 0.469 & 0.292 & \\
$\quad$ Cumulative percentage variance & & & & & \\
$\quad$ of species data & 30.6 & 38.8 & 42.8 & 43.3 & \\
$\quad$ of species-environment relation & 70.8 & 89.5 & 98.9 & 99.9 & \\
& Sum of all eigenvalues & & & & & 1 \\
& Sum of all canonical eigenvalues & & & & & 0.433 \\
\hline Streams & Eigenvalues & 0.131 & 0.021 & 0.002 & 0.001 & 1 \\
& *Lengths of gradient & 3.41 & 3.52 & 2.39 & 2.24 & \\
$\quad$ Species-environment correlations & 0.449 & 0.353 & 0.219 & 0.183 & \\
$\quad$ Cumulative percentage variance & & & & & \\
$\quad$ of species data & 13.1 & 15.2 & 15.4 & 15.5 & \\
$\quad$ of species-environment relation & 84.3 & 98 & 99.2 & 99.6 & \\
$\quad$ Sum of all eigenvalues & & & & & 0.155 \\
$\quad$ Sum of all canonical eigenvalues & & & & & \\
\hline
\end{tabular}



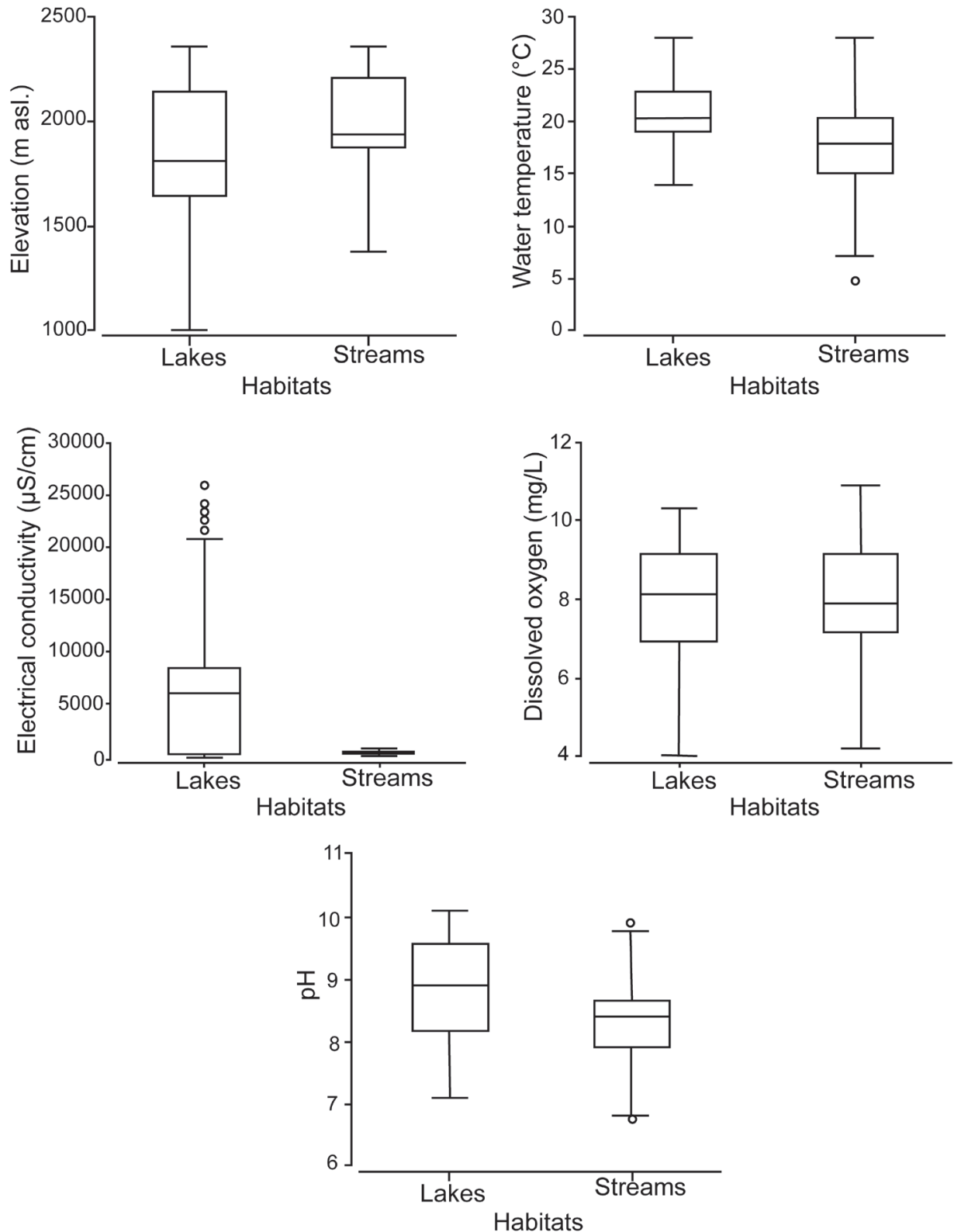

Fig. S1. Comparison of the mean values of elevation, water temperature, electrical conductivity, dissolved oxygen and $\mathrm{pH}$ between lakes and streams in the present study 
